\title{
Kemitraan Konservasi Sebagai Upaya Penyelesaian Konflik Tenurial dalam Pengelolaan Kawasan Konservasi di Indonesia
}

\author{
Dessy Eko Prayitno ${ }^{1}$
}

\begin{abstract}
Abstrak
Kawasan konservasi Indonesia yang luasnya mencapai 27,14 juta hektare dikelilingi kurang lebih 6.381 desa yang menggantungkan kehidupannya kepada kawasan konservasi. Akibatnya terjadi konflik antara masyarakat dengan pengelola kawasan konservasi. Konflik terjadi karena adanya perbedaan kepentingan. Di satu sisi, masyarakat membutuhkan penghidupan dari kawasan konservasi, kemudian di sisi yang lain, pengelola kawasan konservasi memiliki mandat untuk menjaga keutuhan, keaslian, dan kelestarian kawasan konservasi. Dalam situasi konflik kepentingan tersebut, pemerintah mengeluarkan kebijakan kemitraan konservasi. Tulisan ini merupakan penelitian hukum dengan pendekatan peraturan perundang-undangan (statute approach) dan pendekatan historis (historical approach). Tulisan ini akan menelaah dan menguraikan perkembangan pengaturan mengenai kemitraan konservasi yang dimulai dari UU No. 5/1990 hingga yang terakhir adalah Perdirjen KSDAE No. 6/2018, catatan-catatan kritis terhadap Perdirjen KSDAE No. 6/2018, dan optimalisasi Perdirjen KSDAE No. 6/2018 sebagai salah satu pilihan penyelesaian konflik tenurial di kawasan konservasi.
\end{abstract}

Kata kunci: kawasan konservasi, konflik tenurial, kemitraan konservasi.

\section{Abstract}

Indonesia's conservation area which covers 27.14 million hectares is surrounded by approximately 6,381 villages that depend their lives on conservation areas. The result is a conflict between the community and the manager of the conservation area. Conflicts occur because of differences in interests. The community needs livelihood from the conservation area, then on the other hand, the manager of the conservation area has a mandate to maintain the integrity, authenticity, and preservation of the conservation area. In a situation of conflict of interest, the government issues a conservation partnership policy. This paper is a legal research with a statutory approach and a historical approach. This paper will examine and describe the development of the policies regarding conservation partnerships that began with Law No. 5/1990 until the latest is DG KSDAE Regulation No. 6/2018, critical notes to DG KSDAE Regulation No. 6/2018, and optimization of DG KSDAE Regulation No. 6/2018 as an option for tenurial conflicts handling mechanism in conservation areas.

Keywords: conservation area, tenurial conflict, conservation partnership.

${ }^{1}$ Penulis adalah Mahasiswa Pascasarjana Fakultas Hukum Universitas Indonesia, Peminatan Hukum Sumber Daya Alam. 
Kemitraan Konservasi Sebagai Upaya Penyelesaian Konflik Tenurial dalam Pengelolaan Kawasan

\section{Pendahuluan}

Indonesia memiliki kawasan ${ }^{2}$ konservasi dengan luas mencapai 27,14 juta hektare, ${ }^{3}$ yang terbagi menjadi 552 unit pengelolaan kawasan konservasi. ${ }^{4}$ Rincian 552 unit pengelolaan kawasan konservasi meliputi: 214 cagar alam, 79 suaka margasatwa, 131 taman wisata alam, 34 taman hutan raya, 11 taman buru, 54 taman nasional, dan 29 unit kawasan yang masih berstatus kawasan suaka alam (KSA)/kawasan pelestarian alam (KPA). ${ }^{5}$ Selain itu, hingga tahun 2017, telah terbentuk 12 unit kelembagaan kawasan ekosistem esensial (KEE), yang terdiri dari 6 taman keanekaragaman hayati, 2 KEE mangrove, dan 4 KEE koridor satwa. ${ }^{6}$
Menurut Wiratno (2018), sebagaimana dikutip Agus Mulyana, dkk., kawasan konservasi di Indonesia dikelilingi oleh kurang lebih 6.381 desa definitif yang di dalamnya terdapat sekitar 134 komunitas adat. ${ }^{7}$ Jika kita menilik sejarah, penetapan kawasan konservasi dimulai sejak zaman Pemerintahan Hindia-Belanda, tepatnya ketika Pemerintah Hindia-Belanda mengeluarkan Natuurmonumenten Ordonantie atau Undang-Undang Monumen Alam/Cagar Alam Tahun 1916, ${ }^{8}$ yang kemudian diikuti dengan keluarnya Natuurmonumenten en Wildreservaten Ordonantie Tahun 1932 dan Natuurbescherming Ordonantie Tahun 1941. ${ }^{9}$ Kemudian, di masa kemerdekaan, penetapan kawasan konservasi dimulai

\footnotetext{
${ }^{2}$ Nomenklatur "kawasan" ini digunakan untuk menerangkan bahwa kawasan konservasi meliputi kawasan yang berbasis terestrial/lahan (darat) dan kawasan yang berbasis perairan sebagaimana dimaksud dalam Undang-Undang No. 5 Tahun 1990 tentang Konservasi Sumber Daya Alam Hayati dan Ekosistemnya (UU No. 5/1990). Hal tersebut berbeda dengan Undang-Undang No. 41 Tahun 1999 tentang Kehutanan (UU No. 41/1999) yang hanya mengatur kawasan konservasi yang berbasis terestrial/lahan (darat). Lihat Pasal 1 angka 8, angka 9, dan angka 10 UU No. 41/1999 jo Pasal 1 angka 9 dan angka 13 UU No. 5/1990.

${ }^{3}$ Kepala Sub Bagian Data dan Informasi Sekretariat Direktorat Jenderal KSDAE, Statistik Direktorat Jenderal Konservasi Sumber Daya Alam dan Ekosistem 2017, Jakarta: Kementerian Lingkungan Hidup dan Kehutanan, Direktorat Jenderal Konservasi Sumber Daya Alam dan Ekosistem, 2018. Hlm. x.

${ }^{4}$ Ibid.

${ }^{5} \mathrm{Ibid}$.

${ }^{6} \mathrm{Ibid}$.

${ }^{7}$ Agus Mulyana, dkk, Ruang Adaptif: Refleksi Penataan Zona/Blok Di Kawasan Konservasi, (Jakarta: Kementerian Lingkungan Hidup dan Kehutanan, Direktorat Jenderal Konservasi Sumber Daya Alam dan Ekosistem, 2019), hlm. 2.

${ }^{8}$ Pandji Yudistira, Sang Pelopor: Peranan Dr. S.H. Koorders dalam Sejarah Perlindungan Alam di Indonesia, (Jakarta: Kementerian Kehutanan, Direktorat Kawasan Konservasi dan Bina Hutan Lindung, Direktorat Jenderal Perlindungan Hutan dan Konservasi Alam, 2014), hlm. 108.

${ }^{9}$ Pandji Yudistira Kusumasumantri, Sejarah 5 Taman Nasional Pertama, (Jakarta: Kementerian Lingkungan Hidup dan Kehutanan, Direktorat Jenderal Konservasi Sumber Daya Alam dan Ekosistem, [s.a.]), hlm 194.
} 
sejak tahun 1947 dengan ditetapkannya suaka alam Bali Barat. ${ }^{10}$ Dari perspektif sejarah ini menunjukkan bahwa masyarakat (adat) di kawasan konservasi sudah ada sebelum kawasan konservasi ditetapkan sebagai unit-unit pengelolaan kawasan konservasi yang dimulai sejak tahun 1947.

Penetapan unit-unit pengelolaan kawasan konservasi seringkali memunculkan konflik antara pemerintah dan masyarakat yang sudah lebih dulu tinggal atau berkegiatan di dalam kawasan konservasi tersebut. Beberapa contoh konflik yang terjadi antara lain: ${ }^{11}$ pertama, perambahan di Besitang, Taman Nasional Gunung Leuser. Masyarakat merambah kawasan konservasi dengan menanam karet. Jumlah masyarakat yang merambah semakin bertambah sejak tahun 1990-an, dan pada 1999 terjadi pendudukan kawasan konservasi oleh beberapa keluarga pengungsi yang berasal dari Aceh Timur. Pada 2005, jumlah pengungsi dari Aceh Timur mencapai 500 kepala keluarga. Kedua, perambahan di Taman Nasional Tesso Nilo (TNTN) yang terjadi sejak 2002 yang dilakukan oleh masyarakat di sekitar TNTN. Perambahan dilakukan dengan berbagai kepentingan, yaitu: mengambil kayu secara ilegal, mengubah fungsi kawasan konservasi menjadi perkebunan karet atau sawit, dan menjual kawasan konservasi. Dalam kurun waktu 2002-2007, perambahan di TNTN meningkat dari 977 hektare menjadi 8.768 hektare. Ketiga, perambahan di Taman Nasional Bukit Dua Belas (TNBD) oleh 6 desa di Kecamatan Air Hitam, Kabupaten Sarolangun yang masuk dalam kawasan TNBD. Keenam desa tersebut adalah Desa Bukit Suban, Desa Pematang Kabau, Desa Lubuk Jering, Desa Jernih, Desa Semurung, dan Desa Baru. Aktivitas perambahan antara lain berupa perladangan dan perkebunan karet di areal kawasan TNBD. Keempat, konflik penggunaan kawasan konservasi di Taman Nasional Kutai (TNK) untuk kepentingan pertambangan batubara di tujuh desa di Kecamatan Sangatta Selatan. Kelima, konflik penguasaan wilayah adat masyarakat adat Kasepuhan dengan Taman Nasional Gunung Halimun Salak (TNGHS).

Pada tahun 1992, Menteri Kehutanan menetapkan kawasan Gunung Halimun Salak seluas 40.000 hektare menjadi taman nasional. Akibatnya, Balai TNGHS melarang pemukiman di dalam kawasan dan membatasi kegiatan masyarakat di kawasan TNGHS dengan pelarangan

${ }^{10}$ Mahmud, Amir, Arif Satria, dan Rilus A Kinseng, "Analisis Sejarah dan Pendekatan Sentralisasi dalam Pengelolaan Taman Nasional Bali Barat", Jurnal Analisis Kebijakan Kehutanan, Vol. 12 No. 2, (Agustus 2015), hlm. 157.

${ }^{11}$ Lihat Handian Purwawangsa, "Instrumen Kebijakan Untuk Mengatasi Konflik di Kawasan Hutan Konservasi", Risalah Kebijakan Pertanian dan Lingkungan, Vol. 4 No.1, (April 2017), Departemen Manajemen Hutan, Fakultas Kehutanan, Institut Pertanian Bogor. Hlm. 31-37. 
Kemitraan Konservasi Sebagai Upaya Penyelesaian Konflik Tenurial dalam Pengelolaan Kawasan

pengambilan kayu bakar, tanaman obat, dan hasil hutan lainnya. Kemudian, pada tahun 2003, kawasan TNGHS diperluas menjadi 113.357 hektare, yang mencakup seluruh wilayah adat masyarakat adat Kasepuhan. ${ }^{12}$ Dengan masuknya seluruh wilayah adat Kasepuhan ke dalam kawasan taman nasional, maka pemukiman, kegiatan berkebun, berladang, bersawah, dan pengambilan hasil hutan oleh masyarakat adat menjadi dilarang. ${ }^{13}$

Beberapa contoh konflik antara masyarakat dengan taman nasional tersebut, terjadi baik sebelum maupun setelah kawasan konservasi ditetapkan sebagai taman nasional. Konflik-konflik tersebut menunjukkan tingginya ketergantungan masyarakat terhadap kawasan konservasi atau sumber daya hutan. Dalam spektrum yang lebih luas misalnya, dari 75.436 desa di seluruh Indonesia, ${ }^{14}$ lebih dari 25.800 desa berada di dalam dan di sekitar hutan, ${ }^{15}$ dan 6.381 di antaranya berada di kawasan konservasi, ${ }^{16}$ yang semuanya menggantungkan kehidupan- nya pada sumber daya hutan di kawasan konservasi.

Selain menunjukkan ketergantungan masyarakat terhadap kawasan konservasi, konflik-konflik tersebut sekaligus menunjukkan dilema dalam pengelolaan kawasan konservasi, khususnya dikaitkan dengan akses masyarakat terhadap kawasan konservasi. Di satu sisi, pemerintah harus secara optimal menjamin kehidupan dan kesejahteraan masyarakat di dalam dan di sekitar kawasan konservasi, tetapi di sisi lain pemerintah harus membatasi akses masyarakat terhadap kawasan konservasi demi menjaga fungsi konservasinya.

Pembatasan akses ini sebagaimana diatur dalam Pasal 19 dan Pasal 33 Undang-Undang No. 5 Tahun 1990 tentang Konservasi Sumber Daya Alam Hayati dan Ekosistemnya (UU No. 5/1990). Pasal 19 ayat (1) menyatakan bahwa, "setiap orang dilarang melakukan kegiatan yang dapat mengakibatkan perubahan terhadap keutuhan kawasan suaka alam."17 Kemudi-

${ }^{12}$ Ibid., hlm. 36.

${ }^{13} \mathrm{Ibid}$

${ }^{14}$ Badan Pusat Statistik, Berita Resmi Statistik: Hasil Pendataan Potensi Desa (Podes) 2018 No. 99/12/ Th.XXI, 10 Desember 2018, hlm. 1.

${ }^{15}$ Kementerian Lingkungan Hidup dan Kehutanan, "Refleksi Hutan Sosial KLHK 2018: Hutan Untuk Rakyat," Siaran Pers No. SP.723/HUMAS/PP/HMS.3/12/2018, (http://ppid.menlhk.go.id/siaran_pers/browse/1718). Diakses pada 3 Juni 2020.

${ }^{16}$ Wiratno, 10 Cara Baru Kelola Kawasan Konservasi di Indonesia: Membangun Organisasi Pembelajar, (Jakarta: Direktorat Jenderal Konservasi Sumber Daya Alam dan Ekosistem, Kementerian Lingkungan Hidup dan Kehutanan, 2018). Hlm. 03.

${ }_{17}$ Indonesia (1), Undang-Undang No. 5 Tahun 1990 tentang Konservasi Sumber Daya Alam dan Ekosistemnya, ps. 19 ayat (1). 
an Pasal 19 ayat (2) mengatur lebih lanjut mengenai perubahan terhadap keutuhan kawasan, yaitu: mengurangi, menghilangkan fungsi dan luas kawasan suaka alam, serta menambah jenis tumbuhan dan satwa lain yang tidak asli. ${ }^{18}$ Kemudian Pasal 33 mengatur bahwa:19

(1) Setiap orang dilarang melakukan kegiatan yang dapat mengakibatkan perubahan terhadap keutuhan zona inti taman nasional.

(2) Perubahan terhadap keutuhan zona inti taman nasional sebagaimana dimaksud dalam ayat (1) meliputi mengurangi, menghilangkan fungsi dan luas zona inti taman nasional, serta menambah jenis tumbuhan dan satwa lain yang tidak asli.

(3) Setiap orang dilarang melakukan kegiatan yang tidak sesuai dengan fungsi zona pemanfaatan dan zona lain dari taman nasional, taman hutan raya, dan taman wisata alam.

Lebih lanjut, Pasal 1 angka 3 juncto Pasal 13 Peraturan Pemerintah No. 28 Tahun 2011 tentang Pengelolaan Kawasan Suaka Alam dan Kawasan Pelestarian Alam (PP No. 28/2011) mengatur mengenai penyelenggaraan pengelolaan kawasan suaka alam dan kawasan pelestarian alam melalui kegiatan perencana- an, perlindungan, pengawetan, pemanfaatan, pengawasan, dan pengendalian. ${ }^{20}$ Kemudian Pasal 24 mengatur lebih rinci mengenai ruang lingkup kegiatan perlindungan mencakup: (a) pencegahan, penanggulangan, dan pembatasan kerusakan yang disebabkan oleh manusia, ternak, alam, spesies invasif, hama, dan penyakit; dan (b) melakukan penjagaan kawasan secara efektif. ${ }^{21}$ Dalam penjelasan Pasal 24 diuraikan tujuan kegiatan perlindungan, yaitu:22

a. Terjaminnya proses ekologis yang menunjang kelangsungan hidup dari flora, fauna, dan ekosistemnya;

b. Menjaga, mencegah, dan membatasi kegiatan yang dapat mengakibatkan perubahan keutuhan potensi dan kawasan, serta perubahan fungsi kawasan, baik yang disebabkan oleh manusia, ternak, kebakaran alam, spesies invasif, hama, dan penyakit;

c. Menjaga hak negara, masyarakat, dan perorangan atas potensi, kawasan, ekosistem, investasi, dan perangkat yang berhubungan dengan pengelolaan KSA dan KPA; dan

d. Menjamin keutuhan potensi, kawasan, dan fungsi kawasan.

${ }^{18}$ Ibid., ps. 19 ayat (2).

${ }^{19} \mathrm{Ibid} .$, ps. 33.

${ }^{20}$ Indonesia (2), Peraturan Pemerintah No. 28 Tahun 2011 tentang Pengelolaan Kawasan Suaka Alam dan Kawasan Pelestarian Alam, ps. 1 angka 3 juncto ps. 13.

${ }^{21}$ Ibid., ps. 24.

${ }^{22}$ Ibid., Penjelasan ps. 24. 
Kemitraan Konservasi Sebagai Upaya Penyelesaian Konflik Tenurial dalam Pengelolaan Kawasan

Dalam rangka menyeimbangkan kepentingan konservasi dan menjamin kehidupan dan kesejahteraan masyarakat di dalam dan di sekitar kawasan konservasi, pemerintah telah menerbitkan berbagai peraturan perundang-udangan yang memberikan jaminan akses kepada masyarakat untuk memanfaatkan kawasan konservasi. Berbagai peraturan perundang-udangan tersebut mulai dari peraturan pemerintah, peraturan menteri kehutanan (saat ini Kementerian Lingkungan Hidup dan Kehutanan), hingga yang terakhir adalah Peraturan Direktur Jenderal Konservasi Sumber Daya Alam dan Ekosistem No. P.6/KSDAE/SET/ Kum.1/6/2018 tentang Petunjuk Teknis Kemitraan Konservasi Pada Kawasan Suaka Alam dan Kawasan Pelestarian Alam (Perdirjen KSDAE No. 6/2018).

Tulisan ini akan membahas mengenai jaminan akses kepada masyarakat untuk memanfaatkan kawasan konservasi. Fokus utama pembahasan adalah Perdirjen KSDAE No. 6/2018 sebagai sebuah politik hukum untuk menyeimbangkan kepentingan konservasi dan menjamin kehidupan dan kesejahteraan masyarakat di dalam dan di sekitar kawasan konservasi, sekaligus bagaimana Perdirjen KSDAE No. 6/2018 dapat dijadikan sebagai salah satu pilihan penye- lesaian konflik tenurial di kawasan konservasi.

Perdirjen KSDAE No. 6/2018 merupakan mandat dari tiga peraturan, yaitu: (a) Peraturan Menteri Lingkungan Hidup dan Kehutanan No. P.83/MENLHK/SETJEN/KUM.1/10/2016 tentang Perhutanan Sosial (Permenlhk No. 83/2016); (b) Peraturan Menteri Lingkungan Hidup dan Kehutanan No. P.43/ MENLHK/SETJEN/KUM.1/6/ 2017 tentang Pemberdayaan Masyarakat di Sekitar Kawasan Suaka Alam dan Kawasan Pelestarian Alam (Permenlhk No. 43/2017); dan (c) Peraturan Menteri Lingkungan Hidup dan Kehutanan No. P.44/MENLHK/SETJEN/ KUM.1/6/2017 tentang Perubahan Atas Peraturan Menteri Kehutanan No. P.85/ Menhut-II/2014 tentang Tata Cara Kerjasama Penyelenggaraan Kawasan Suaka Alam dan Kawasan Pelestarian Alam (Permenlhk No. 44/2017). Perdirjen ini mengatur mengenai tata cara penyelenggaraan, pembinaan, pengendalian, dan pengawasan pelaksanaan kemitraan konservasi. ${ }^{23}$ Kemudian dari sisi tujuan, Perdirjen ini bertujuan untuk mewujudkan kemandirian dan kesejahteraan masyarakat untuk berpartisipasi dalam pengelolaan dan pelestarian kawasan konservasi. ${ }^{24}$

\footnotetext{
${ }^{23}$ Kementerian Lingkungan Hidup dan Kehutanan (1), Peraturan Direktur Jenderal Konservasi Sumber Daya Alam dan Ekosistem No. P.6/KSDAE/SET/Kum.1/6/2018 tentang Petunjuk Teknis Kemitraan Konservasi Pada Kawasan Suaka Alam dan Kawasan Pelestarian Alam, ps.3.

${ }^{24}$ Ibid., ps. 2 ayat (2).
} 
Tulisan ini merupakan penelitian hukum dengan pendekatan peraturan perundang-undangan (statute approach) dan pendekatan historis (historical approach). Pendekatan peraturan perundang-undangan dilakukan dengan menelaah peraturan perundang-udangan yang terkait dengan pelibatan masyarakat dalam pengelolaan kawasan konservasi. Sedangkan pendekatan historis dilakukan untuk menguraikan perkembangan pengaturan mengenai kemitraan konservasi yang dimulai dari UU No. 5/1990 hingga yang terakhir adalah Perdirjen KSDAE No. 6/2018. Sumber-sumber penelitian hukum ini menggunakan bahan hukum primer, bahan hukum sekunder, dan bahan non-hukum.

\section{Kebijakan Kemitraan Konservasi}

\section{A. Kemitraan (Konservasi) Sebe- lum Perdirjen KSDAE No. 6/2018}

Kemitraan atau pelibatan masyarakat dalam pengelolaan hutan termasuk kawasan konservasi, sebenarnya sudah dilakukan pemerintah sejak lama. Jika merunut dari berbagai kebijakan pemerintah, kemitraan atau pelibatan masyarakat dalam pengelolaan hutan dimulai sejak lahirnya UU No. 5/1990 hingga saat ini. Berikut ini akan diuraikan satu-satu mengenai kebijakan kemitraan atau pelibatan masyarakat dalam pengelolaan kawasan konservasi hingga sebelum lahirnya Perdirjen KSDAE No. 6 Tahun 2018.

Pertama, UU No. 5/1990. Setidaknya terdapat tiga pasal dalam UU No. 5/1990 yang menegaskan peran serta masyarakat dalam pengelolaan kawasan konservasi, yaitu Pasal 4, Penjelasan Pasal 10, dan Pasal 37. Ketiga pasal tersebut pada intinya menegaskan bahwa konservasi sumber daya alam hayati dan ekosistemnya merupakan tanggung jawab dan kewajiban pemerintah serta masyarakat, ${ }^{25}$ dan pemerintah perlu mengikutsertakan masyarakat dalam rehabilitasi kawasan konservasi akibat bencana alam (longsor, erosi, kebakaran, dan gempa bumi) atau pemanfaatan kawasan konservasi yang tidak tepat. ${ }^{26}$

Kedua, Peraturan Menteri Kehutanan No. P.19/Menhut-II/2004 tentang Kolaborasi Pengelolaan Kawasan Suaka Alam dan Kawasan Pelestarian Alam (Permenhut No. 19/2004) yang juga mengatur mengenai pelibatan berbagai pihak ${ }^{27}$

\footnotetext{
${ }^{25}$ Indonesia (1), Op.Cit., ps. 4.

${ }^{26}$ Ibid., Penjelasan ps. 10.
}

27 Pihak-pihak terkait ini antara lain: (a) Pemerintah Pusat, termasuk Kepala UPT KSDA/TN; (b) Pemerintah Daerah; (c) Kelompok Masyarakat setempat; (d) Perorangan, baik dari dalam maupun luar negeri; (e) Lembaga Swadaya Masyarakat setempat, nasional, dan internasional yang bekerja dibidang konservasi sumber daya alam hayati; (f) BUMN, BUMD, BUMS; atau (g) Perguruan Tinggi/lembaga ilmiah/lembaga pendidikan. Lihat Kementerian Kehutanan (1), Peraturan Menteri Kehutanan No. P.19/Menhut-II/2004 tentang Kolaborasi Pengelolaan Kawasan Suaka Alam dan Kawasan Pelestarian Alam, ps. 4 ayat (3). 
Kemitraan Konservasi Sebagai Upaya Penyelesaian Konflik Tenurial dalam Pengelolaan Kawasan

untuk meningkatkan pengelolaan kawasan suaka alam dan kawasan pelestarian alam. Terminologi pelibatan yang digunakan dalam Permenhut ini adalah kolaborasi. Dan apabila dicermati secara keseluruhan, titik berat kolaborasinya adalah dalam rangka mendukung, memperkuat, dan meningkatkan upaya-upaya pemerintah dalam mengelola kawasan suaka alam dan kawasan pelestarian alam sesuai dengan kondisi fisik, sosial, budaya, dan aspirasi setempat. ${ }^{28}$ Yang menarik adalah, dalam konsiderans Menimbang, Permenhut No. 19/2004 tidak menyebutkan mandat penyusunannya.

Ketiga, Peraturan Menteri Kehutanan No. P.56/Menhut-II/2006 tentang Pedoman Zonasi Taman Nasional (Permenhut No. 56/2006). Permenhut ini merupakan amanat dari Pasal 30 ayat (2) Peraturan Pemerintah No. 68 Tahun 1998 tentang Kawasan Suaka Alam dan Kawasan Pelestarian Alam (PP No. 68/1998). Permenhut No. 56/2006 mengatur mengenai peran serta masyarakat dalam penetapan zonasi taman nasional. ${ }^{29} \mathrm{Pe}-$ ran serta masyarakat yang diharapkan antara lain: "(a) memberi saran, informasi, dan pertimbangan; (b) memberikan dukungan dalam pelaksanaan kegiatan zonasi; (c) melakukan pengawasan kegiatan zonasi; dan (d) ikut menjaga dan memelihara zonasi." ${ }^{\prime 30}$ Urgensi keterlibatan masyarakat dalam penetapan zonasi taman nasional adalah dalam rangka memastikan ruang-ruang yang tepat bagi keperluan pengelolaan kawasan konservasi di tingkat tapak, sekaligus mengakomodir berbagai kepentingan masyarakat dalam pemanfaatan kawasan konservasi. ${ }^{31}$ Penetapan zonasi ini sangat potensial dalam menempatkan masyarakat menjadi satu kesatuan yang tidak terpisahkan dari kawasan konservasi. ${ }^{32}$ Yang menarik adalah, PP No. 68/1998 yang menjadi dasar lahirnya Permenhut No. 56/2006, ternyata sama sekali belum mengatur mengenai peran serta masyarakat dalam pengelolaan kawasan konservasi.

Keempat, Peraturan Menteri Kehutanan No. P.39/Menhut-II/2013 tentang Pemberdayaan Masyarakat Setempat

${ }^{28}$ Ibid., Pasal 3. Lihat pula Lampiran Pasal 4 ayat (2), Pasal 4 ayat (5) dan ayat (6), Pasal 9 ayat (2) yang semakin menegaskan bahwa tujuan kolaborasi dalam Permenhut No. 19/2004 ini adalah dalam rangka membantu pemerintah dalam pengelolaan kawasan konservasi.

${ }^{29}$ Zonasi taman nasional adalah suatu proses pengaturan ruang dalam taman nasional menjadi zona-zona, yang mencakup kegiatan tahap persiapan, pengumpulan dan analisis data, penyusunan draf rancangan zonasi, konsultasi publik, perancangan, tata batas, dan penetapan, dengan mempertimbangkan kajian-kajian dari aspek-aspek ekologis, sosial, ekonomi dan budaya masyarakat. Lihat Kementerian Kehutanan (2), Peraturan Menteri Kehutanan No. P.56/Menhut-II/2006 tentang Pedoman Zonasi Taman Nasional, ps. 1 angka 2.

${ }^{30}$ Ibid., ps. 19 ayat (2).

${ }^{31}$ Lihat Agus Mulyana, dkk., Op.Cit., hlm.,3.

${ }^{32}$ Ibid., Hlm. 4. 
Melalui Kemitraan Kehutanan (Permenhut No. 39/2013). Permenhut ini merupakan amanat Pasal 99 ayat (5) Peraturan Pemerintah No. 6 Tahun 2007 tentang Tata Hutan dan Penyusunan Rencana Pengelolaan Hutan, serta Pemanfaatan Hutan. Permenhut ini mengatur kemitraan dalam lingkup yang lebih luas, yaitu antara masyarakat setempat dengan Pemegang Izin pemanfaatan hutan atau Pengelola Hutan, Pemegang Izin usaha industri primer hasil hutan, dan/atau Kesatuan Pengelolaan Hutan dalam pengembangan kapasitas dan pemberian akses, dengan prinsip kesetaraan dan saling menguntungkan. ${ }^{33}$ Dari sisi tujuan, kemitraan ini bertujuan untuk meningkatkan kemampuan dan kemandirian masyarakat setempat, serta memberikan akses kepada masyarakat untuk mendapatkan manfaat sumber daya hutan secara optimal dan adil. ${ }^{34}$

Kelima, Peraturan Menteri Kehutanan No. P.85/Menhut-II/2014 tentang Tata Cara Kerjasama Penyelenggaraan
Kawasan Suaka Alam dan Kawasan Pelestarian Alam (Permenhut No. 85/2014). Permenhut ini merupakan amanat Pasal 43 ayat (3) PP No. 28/2011. Kerja sama yang didorong Permenhut ini sama dengan kolaborasi sebagaimana dimandatkan dalam Permenhut No. 19/2004, yaitu ditujukan untuk optimalisasi dan efektifitas pengelolaan kawasan atau karena adanya pertimbangan khusus bagi penguatan ketahanan nasional. ${ }^{35}$ Lingkup kerja samanya secara umum ada dua, yaitu: ${ }^{36}$ (a) penguatan fungsi kawasan suaka alam dan kawasan pelestarian alam, serta konservasi keanekaragaman hayati; ${ }^{37}$ dan (b) pembangunan strategis yang tidak dapat dielakkan. ${ }^{38}$ Para pihak yang diharapkan dapat terlibat dalam kerja sama ini antara lain: badan usaha, lembaga internasional, instansi pemerintah/lembaga negara, pemerintah daerah, kelompok masyarakat, lembaga swadaya masyarakat, perorangan, lembaga pendidikan, dan/atau yayasan. ${ }^{39}$

\footnotetext{
${ }^{33}$ Kementerian Kehutanan (3), Peraturan Menteri Kehutanan No. P.39/Menhut-II/2013 tentang Pemberdayaan Masyarakat Setempat Melalui Kemitraan Kehutanan, ps. 1 angka 3.

${ }^{34} \mathrm{Ibid.}$., ps. 1 angka 1 juncto ps. 2 dan (3).

${ }^{35}$ Kementerian Kehutanan (4), Peraturan Menteri Kehutanan No. P.85/Menhut-II/2014 tentang Tata Cara Kerjasama Penyelenggaraan Kawasan Suaka Alam dan Kawasan Pelestarian Alam, ps. 1 angka 6.

${ }^{36}$ Ibid., ps. 3.

${ }^{37} \mathrm{Ibid} .$, ps. 6. Kerja sama penguatan fungsi mencakup kerja sama: (a) penguatan kelembagaan; (b) perlindungan kawasan; (c) pengawetan flora dan fauna; (d) pemulihan ekosistem; (e) pengembangan wisata alam; atau (f) pemberdayaan masyarakat.

${ }^{38}$ Ibid., ps. 13, 14, 15, 16, dan 17. Kerja sama pembangunan strategis mencakup: (a) kegiatan yang mempunyai pengaruh terhadap kedaulatan negara dan pertahanan keamanan negara; (b) pemanfaatan dan pengembangan sarana komunikasi; (c) pemanfaatan dan pengembangan transportasi terbatas; atau (d) pemanfaatan dan pengembangan energi baru dan terbarukan, serta jaringan listrik untuk kepentingan nasional.

${ }^{39}$ Ibid., ps. 5.
} 
Kemitraan Konservasi Sebagai Upaya Penyelesaian Konflik Tenurial dalam Pengelolaan Kawasan

Keenam, Permenlhk No. 43/2017. Permenlhk ini merupakan amanat Pasal 49 ayat (6) PP No. 28/2011. Kerja sama yang didorong dalam Permenlhk ini adalah untuk mengembangkan kemandirian dan kesejahteraan masyarakat di sekitar kawasan suaka alam dan kawasan pelestarian alam untuk mendukung kelestarian kawasan konservasi..$^{40}$ Pengembangan kemandirian dan kesejahteraan masyarakat dilakukan melalui: (a) pengembangan desa konservasi; (b) pemberian akses; (c) fasilitasi kemitraan; (d) pemberian izin pengusahaan jasa wisata alam; dan (e) pembangunan pondok wisata. $^{41}$
Ketujuh, Permenlhk No. 44/2017. Sebagaimana namanya, Permenlhk ini merupakan revisi dari Permenhut No. 85/2014. Salah satu perbaikan utama dalam Permenlhk ini adalah masuknya kerja sama kemitraan konservasi dalam rangka pemulihan ekosistem antara unit pengelola kawasan konservasi dengan masyarakat dalam rangka mengembalikan fungsi kawasan suaka alam dan kawasan pelestarian alam. ${ }^{42}$

Secara sederhana, ketujuh milestone kebijakan kemitraan atau pelibatan masyarakat dalam pengelolaan kawasan konservasi sebagaimana diuraikan sebelumnya dapat ditunjukkan dalam tabel berikut ini:

\begin{tabular}{|l|l|l|}
\hline Peraturan & $\begin{array}{l}\text { Nomenklatur Kemitra- } \\
\text { an yang Digunakan }\end{array}$ & Posisi/Kedudukan Masyarakat \\
\hline UU No. 5/1990 & Peran serta masyarakat & $\begin{array}{l}\text { Masyarakat masih dalam posisi } \\
\text { pasif, yang masih harus diarahkan } \\
\text { dan digerakkan oleh pemerintah; } \\
\text { Fokus peran serta masyarakat } \\
\text { adalah dalam rangka membantu } \\
\text { pemerintah dalam pengelolaan } \\
\text { kawasan konservasi, sedangkan } \\
\text { hak kesejahteraan masyarakat be- } \\
\text { lum menjadi fokus. }\end{array}$ \\
\hline
\end{tabular}

${ }^{40}$ Kementerian Lingkungan Hidup dan Kehutanan (2), Peraturan Menteri Lingkungan Hidup dan Kehutanan No. P.43/MENLHK/SETJEN/KUM.1/6/2017 tentang Pemberdayaan Masyarakat di Sekitar Kawasan Suaka Alam dan Kawasan Pelestarian Alam, ps. 2.

${ }^{41}$ Ibid., ps. 11.

${ }^{42}$ Kementerian Lingkungan Hidup dan Kehutanan (3), Peraturan Menteri Lingkungan Hidup dan Kehutanan No. P.44/MENLHK/SETJEN/KUM.1/6/2017 tentang Perubahan Atas Peraturan Menteri Kehutanan No. P.85/Menhut-II/2014 tentang Tata Cara Kerjasama Penyelenggaraan Kawasan Suaka Alam dan Kawasan Pelestarian Alam, ps. 12A ayat (2). 


\begin{tabular}{|c|c|c|}
\hline $\begin{array}{l}\text { Permenhut No. } \\
\text { 19/2004 }\end{array}$ & $\begin{array}{l}\text { Kolaborasi } \\
\text { ngelolam pe- } \\
\text { konservasi }\end{array}$ & $\begin{array}{l}\text { Masyarakat menjadi salah satu pi- } \\
\text { hak yang bisa diajak berkolaborasi } \\
\text { dalam pengelolaan kawasan kon- } \\
\text { servasi; } \\
\text { Fokus peran serta masyarakat } \\
\text { adalah dalam rangka membantu } \\
\text { pemerintah dalam pengelolaan } \\
\text { kawasan konservasi, sedangkan } \\
\text { hak kesejahteraan masyarakat be- } \\
\text { lum menjadi fokus. }\end{array}$ \\
\hline $\begin{array}{l}\text { Permenhut No. } \\
56 / 2006\end{array}$ & $\begin{array}{l}\text { Peran serta dalam pe- } \\
\text { netapan zonasi taman } \\
\text { nasional }\end{array}$ & $\begin{array}{l}\text { Peran masyarakat masih dalam ta- } \\
\text { taran memberikan informasi dan } \\
\text { masukan, belum pada tingkat ke- } \\
\text { terlibatan dalam pengambilan ke- } \\
\text { putusan; } \\
\text { Fokus peran serta masyarakat } \\
\text { adalah dalam rangka membantu } \\
\text { pemerintah dalam pengelolaan } \\
\text { kawasan konservasi, sedangkan } \\
\text { hak kesejahteraan masyarakat be- } \\
\text { lum menjadi fokus. }\end{array}$ \\
\hline $\begin{array}{l}\text { Permenhut No. } \\
39 / 2013\end{array}$ & $\begin{array}{l}\text { Pemberdayaan masya- } \\
\text { rakat melalui kemitraan } \\
\text { kehutanan }\end{array}$ & $\begin{array}{l}\text { Masyarakat menjadi salah satu } \\
\text { pihak yang bisa diajak bermitra } \\
\text { dalam pengelolaan kawasan kon- } \\
\text { servasi; } \\
\text { Kemitraan juga melibatkan peme- } \\
\text { gang izin pemanfaatan kawasan; } \\
\text { Fokus kemitraan tidak hanya } \\
\text { membantu pemerintah untuk me- } \\
\text { ningkatkan kinerja pengelolaan } \\
\text { kawasan, tetapi juga memberikan } \\
\text { akses kepada masyarakat untuk } \\
\text { mendapatkan manfaat sumber } \\
\text { daya hutan secara optimal dan } \\
\text { adil. }\end{array}$ \\
\hline $\begin{array}{l}\text { Permenhut No. } \\
85 / 2014\end{array}$ & $\begin{array}{l}\text { Kerja sama dalam pe- } \\
\text { ngelolaan } \\
\text { konservasi }\end{array}$ & $\begin{array}{l}\text { Masyarakat menjadi salah satu pi- } \\
\text { hak yang bisa diajak bekerja sama } \\
\text { dalam pengelolaan kawasan kon- } \\
\text { servasi; Fokus peran serta masya- } \\
\text { rakat adalah dalam rangka }\end{array}$ \\
\hline
\end{tabular}


Kemitraan Konservasi Sebagai Upaya Penyelesaian Konflik Tenurial dalam Pengelolaan Kawasan

\begin{tabular}{|l|l|l|}
\hline & & $\begin{array}{l}\text { membantu pemerintah dalam pe- } \\
\text { ngelolaan kawasan konservasi, } \\
\text { sedangkan hak kesejahteraan ma- } \\
\text { syarakat belum menjadi fokus. }\end{array}$ \\
\hline $\begin{array}{l}\text { Permenlhk No. } \\
43 / 2017\end{array}$ & $\begin{array}{l}\text { Pemberdayaan masya- } \\
\text { rakat di sekitar kawa- } \\
\text { san konservasi }\end{array}$ & $\begin{array}{l}\text { Masyarakat yang diberdayakan } \\
\text { hanya masyarakat yang berada di } \\
\text { luar kawasan konservasi; } \\
\text { Fokus kemitraan tidak hanya } \\
\text { membantu pemerintah untuk me- } \\
\text { ningkatkan kinerja pengelolaan } \\
\text { kawasan, tetapi juga memberikan } \\
\text { akses kepada masyarakat untuk } \\
\text { mendapatkan manfaat sumber } \\
\text { daya hutan secara optimal dan } \\
\text { adil. }\end{array}$ \\
\hline $\begin{array}{l}\text { Permenlhk No. } \\
44 / 2017\end{array}$ & $\begin{array}{l}\text { Kerja sama dalam pe- } \\
\text { ngelolaan } \\
\text { konservasi } \\
\text { kawasan }\end{array}$ & $\begin{array}{l}\text { Masyarakat menjadi salah satu pi- } \\
\text { hak yang bisa diajak bekerja sama } \\
\text { dalam pengelolaan kawasan kon- } \\
\text { servasi; } \\
\text { Fokus peran serta masyarakat } \\
\text { adalah dalam rangka membantu } \\
\text { pemerintah dalam pengelolaan } \\
\text { kawasan konservasi, sedangkan } \\
\text { hak kesejahteraan masyarakat be- } \\
\text { lum menjadi fokus. }\end{array}$ \\
\hline
\end{tabular}

Tabel 3. Milestone Kebijakan Kemitraan Konservasi

Sebelum Lahirnya Perdirjen KSDAE No. 6/2018 


\section{B. Kemitraan Konservasi dalam Perdirjen KSDAE No. 6/2018}

\section{Substansi Pengaturan}

Sebagaimana telah disebutkan di awal bahwa Perdirjen KSDAENo. 6/2018 merupakan mandat dari tiga peraturan, yaitu: (a) Permenlhk No. 83/2016;43 (b) Permenlhk No. 43/2017; ${ }^{44}$ dan (c) Permenlhk No. 44/2017. ${ }^{45}$ Jika melihat mandat yang sekaligus menjadi konsiderans menimbang Perdirjen KSDAE No. 6/2018, maka sesungguhnya Perdirjen KSDAE No. 6/2018 ini mengombinasikan semangat perubahan dalam ketiga peraturan tersebut. Hal mana semangat perubahan dalam Perdirjen KSDAE No. 6/2018 ini kemudian membedakannya dari kemitraan atau pelibatan masyarakat dalam pengelolaan kawasan konservasi sebagaimana diatur dalam ketujuh peraturan yang telah diulas dalam Bagian II.1. Kemitraan (Konservasi) Sebelum Perdirjen KSDAE No. 6/ 2018.

Semangat perubahan itu antara lain: pertama, Perdirjen KSDAE No. 6/2018 memosisikan masyarakat sebagai mitra dalam pengelolaan kawasan konservasi.
Artinya, keterlibatan masyarakat dimulai sejak dari pengusulan kemitraan konservasi kepada unit pengelola kawasan konservasi, menyusun rencana kemitraan, melaksanakan kemitraan konservasi, dan melakukan monitoring dan evaluasi pelaksanaan kemitraan konservasi. Semangat pertama ini terinspirasi dari Permenlhk No. 83/2016 yang mengatur mengenai perhutanan sosial. Perolehan skema perhutanan sosial, baik terhadap hak pengusahaan hutan desa, izin usaha pemanfaatan hutan kemasyarakatan, izin usaha pemanfaatan hasil hutan kayu pada hutan tanaman rakyat, kemitraan kehutanan, dan hutan adat diajukan secara aktif oleh masyarakat. ${ }^{46}$ Kedua, Perdirjen KSDAE No. 6/2018 memosisikan masyarakat sebagai mitra yang setara dalam pengelolaan kawasan konservasi. Hal ini terlihat dari skema legalisasi kemitraan konservasi yang menggunakan skema perjanjian kerja sama, alih-alih menggunakan skema izin. Ketiga, Perdirjen KSDAE No. 6/2018 mengatur dua ruang lingkup kemitraan konservasi, yaitu: kemitraan konservasi dalam rangka

\footnotetext{
${ }^{43}$ Kementerian Lingkungan Hidup dan Kehutanan (4), Peraturan Menteri Lingkungan Hidup dan Kehutanan No. P.83/MENLHK/SETJEN/KUM.1/10/2016 tentang Perhutanan Sosial, Pasal 49 ayat (2) Menyatakan bahwa: "ketentuan teknis kemitraan kehutanan dalam kawasan konservasi sebagaimana dimaksud pada ayat (1) diatur lebih lanjut oleh Direktur Jenderal yang membidangi Konservasi Sumber Daya Alam dan Ekosistem.

${ }^{44}$ Kementerian Lingkungan Hidup dan Kehutanan (2), Op.Cit., ps. 13, ps. 14, dan ps. 15. Mencermati ketiga pasal tersebut, sebenarnya hanya ps. 14 dan ps. 15 yang memandatkan pengaturan lebih lanjut Permenlhk No. 43/2017, yaitu terhadap: (a) tata cara pemungutan dan persyaratan pemberian akses pemungutan hasil hutan bukan kayu; dan (b) lokasi kegiatan pemanfaatan tradisional.

${ }^{45}$ Kementerian Lingkungan Hidup dan Kehutanan (3), Op.Cit., ps. 12A ayat (4).

${ }^{46}$ Kementerian Lingkungan Hidup dan Kehutanan (4), Op.Cit., ps. 8, ps.13, ps.19, ps. 24, ps. 30, ps. 35 , ps. 44 , dan ps. 50.
} 
Kemitraan Konservasi Sebagai Upaya Penyelesaian Konflik Tenurial dalam Pengelolaan Kawasan

pemberdayaan masyarakat dan kemitraan konservasi dalam rangka pemulihan ekosistem. Dua skema ini mengombinasikan skema pemberdayaan masyarakat sebagaimana diatur dalam Permenlhk No. 43/2017 dan skema pemulihan ekosistem sebagaimana diatur dalam Permenlhk No. 44/2017. Dua skema ini menjamin pemanfaatan hasil hutan bukan kayu (HHBK) yang diperoleh dari kawasan konservasi.

Berikut ini akan diuraikan secara rinci mengenai kemitraan konservasi sebagaimana diatur dalam Perdirjen KSDAE No. 6/2018. Perdirjen ini terdiri dari 40 pasal yang terbagi kedalam delapan bab, yaitu:

\begin{tabular}{|l|l|}
\hline Bab & \multicolumn{1}{|c|}{ Substansi Pengaturan } \\
\hline Bab I Ketentuan Umum & $\begin{array}{l}\text { Berisi mengenai pengertian-pengertian yang digunakan } \\
\text { dalam Perdirjen ini. Salah satu pengertian yang diatur } \\
\text { dalam Bab ini adalah kemitraan kehutanan di dalam ka- } \\
\text { wasan konservasi atau yang kini lebih dikenal sebagai } \\
\text { kemitraan konservasi, yaitu kerja sama antara kepala } \\
\text { unit pengelola kawasan atau pemegang izin pada ka- } \\
\text { wasan konservasi dengan masyarakat setempat berda- } \\
\text { sarkan prinsip saling menghargai, saling percaya, dan } \\
\text { saling menguntungkan. } \\
\text { Pengaturan berikutnya dalam Bab I ini adalah menge- } \\
\text { nai maksud dan tujuan diundangkannya Perdirjen ini, } \\
\text { yaitu: (a) memberikan panduan kepada unit pengelola } \\
\text { kawasan konservasi dalam melaksanakan kemitraan } \\
\text { konservasi; dan (b) mewujudkan kemandirian dan ke- } \\
\text { sejahteraan masyarakat dalam rangka penguatan tata } \\
\text { kelola dan fungsi kawasan konservasi dan kelestarian } \\
\text { keanekaragaman hayati. } \\
\text { Pengaturan terakhir dalam Bab I ini adalah terkait de- } \\
\text { ngan ruang lingkup dua kemitraan konservasi, yaitu: } \\
\text { (a) kemitraan konservasi dalam rangka pemberdayaan } \\
\text { masyarakat; dan (b) kemitraan konservasi dalam rangka } \\
\text { pemulihan ekosistem. }\end{array}$ \\
\hline
\end{tabular}

\footnotetext{
${ }^{47}$ Kementerian Lingkungan Hidup dan Kehutanan (1), Op.Cit., ps. 1 angka 13.
} 

Bab II Kemitraan Konser-
vasi dalam Rangka Pem-
berdayaan Masyarakat
Bentuk kemitraan konservasi: (a) pemberian akses; dan (b) kerja sama antara pemegang izin pada kawasan konservasi dengan masyarakat setempat, dengan jangka waktu lima tahun dengan perpanjangan.

Pemberian akses mencakup:

a. pemungutan hasil hutan bukan kayu (HHBK) (rotan, getah, damar, biji-bijian, bunga-bungaan, daun-daunan, akar-akaran, kulit kayu, bambu hutan, buah-buahan, umbi-umbian, nibung, lilin tawon, madu, sagu, nipah, ijuk, tumbuhan obat, dan jamur).

b. budidaya tradisional (budidaya tanaman obat dan budidaya tanaman untuk kebutuhan sehari-hari).

c. perburuan tradisional untuk jenis yang tidak dilindungi untuk kepentingan yang bersifat mendesak untuk upacara adat keagamaan dan pemenuhan kebutuhan sehari-hari.

d. pemanfaatan tradisional sumber daya perairan terbatas untuk jenis yang tidak dilindungi; dan

e. wisata alam terbatas.

Lokasi kemitraan konservasi:

a. Secara umum lokasinya meliputi zona/blok tradisional dan blok pemanfaatan kawasan pelestarian alam;

b. Lokasi untuk pemungutan HHBK, budidaya tradisional, perburuan tradisional, pemanfaatan sumber daya perairan dilaksanakan di zona/blok tradisional atau zona/blok yang memiliki fungsi untuk pemanfaatan tradisional.

Dalam Bab II ini diatur pula mengenai syarat mengajukan kemitraan konservasi dan tahapan pelaksanaannya, yang meliputi tahap persiapan, usulan rencana kegiatan, penilaian dan persetujuan, serta perumusan dan penandatanganan perjanjian kerja sama kemitraan konservasi. Di setiap tahapan ini, masyarakat aktif dalam proses penyiapan dokumen dan pengusulannya hingga proses penetapannya. 
Kemitraan Konservasi Sebagai Upaya Penyelesaian Konflik Tenurial dalam Pengelolaan Kawasan

\begin{tabular}{|c|c|}
\hline $\begin{array}{l}\text { ab III Kemitraan Konser- } \\
\text { asi dalam Rangka Pemu- } \\
\text { han Ekosistem }\end{array}$ & $\begin{array}{l}\text { Kemitraan konservasi dalam rangka pemulihan ekosis- } \\
\text { tem dilaksanakan pada ekosistem yang rusak di kawa- } \\
\text { san konservasi dan ditujukan untuk memulihkan eko- } \\
\text { sistem yang rusak tersebut. } \\
\text { Kemitraan konservasi dilakukan dengan ketentuan: } \\
\text { a. Kesepakatan bahwa areal yang dipulihkan merupa- } \\
\text { kan kawasan konservasi dan tidak akan memperlu- } \\
\text { as areal garapan; } \\
\text { b. Tujuan utama kemitraan adalah untuk memulihkan } \\
\text { kondisi ekosistem kawasan konservasi ke tingkat/ } \\
\text { mendekati kondisi aslinya atau sesuai dengan target } \\
\text { pemulihan yang ditetapkan; } \\
\text { c. Pemulihan ekosistem dilakukan secara bertahap; } \\
\text { d. Adanya kesepakatan dari masyarakat mengenai } \\
\text { program dan jaminan untuk beralih mata pencahari- } \\
\text { an/ketergantungan pada kawasan konservasi; } \\
\text { e. Jangka waktu kemitraan maksimal } 10 \text { tahun atau } \\
\text { satu daur. } \\
\text { Lokasi kemitraan konservasi dalam rangka pemulihan } \\
\text { ekosistem dilaksanakan di zona rehabilitasi taman na- } \\
\text { sional atau blok rehabilitasi suaka margasatwa, taman } \\
\text { hutan raya atau taman wisata alam atau areal yang telah } \\
\text { mengalami kerusakan dan bukan pada areal jelajah sat- } \\
\text { wa dilindungi atau habitat dilindungi. } \\
\text { Dalam Bab III ini diatur pula mengenai hak dan kewa- } \\
\text { jiban para pihak, tahapan pelaksanaan kemitraan yang } \\
\text { dimulai dari inventarisasi dan identifikasi kerusakan } \\
\text { ekosistem, penyusunan rencana pemulihan ekosistem, } \\
\text { penyusunan dan penandatanganan perjanjian kerja } \\
\text { sama kemitraan konservasi. }\end{array}$ \\
\hline Bab V Pelaporan & $\begin{array}{l}\text { Bab ini mengatur mengenai kewajiban masyarakat un- } \\
\text { tuk menyampaikan laporan pelaksanaan kemitraan } \\
\text { konservasi kepada unit pengelola kawasan konservasi } \\
\text { setiap enam bulan sekali. }\end{array}$ \\
\hline
\end{tabular}




\begin{tabular}{|c|c|}
\hline Bab VI Pembiayaan & $\begin{array}{l}\text { Bab ini mengatur mengenai sumber-sumber pembiaya- } \\
\text { an pelaksanaan kemitraan konservasi, yaitu: anggaran } \\
\text { pendapatan dan belanja negara, anggaran pendapatan } \\
\text { dan belanja daerah, dan anggaran lain yang sah dan ti- } \\
\text { dak mengikat. }\end{array}$ \\
\hline $\begin{array}{l}\text { Bab VII Pembinaan, Pe- } \\
\text { ngendalian, Monitoring } \\
\text { dan Evaluasi }\end{array}$ & $\begin{array}{l}\text { Bab ini mengatur mengenai struktur pembinaan dan pe- } \\
\text { ngendalian pelaksanaan kemitraan konservasi yang di- } \\
\text { laksanakan oleh Dirjen KSDAE dan kepala unit pengelo- } \\
\text { laan kawasan konservasi. Pembinaan dan pengendalian } \\
\text { meliputi pembinaan sumber daya manusia, penegakan } \\
\text { integritas, pengendalian atas pengelolaan sistem infor- } \\
\text { masi, dan pengendalian fisik atas lokasi pemanfaatan di } \\
\text { dalam zona atau blok tradisional. } \\
\text { Bab ini juga mengatur mengenai monitoring dan eva- } \\
\text { luasi yang dilaksanakan oleh kepala unit pengelolaan } \\
\text { kawasan konservasi. Monitoring dan evaluasi dilaksa- } \\
\text { nakan terhadap perkembangan pelaksanaan kemitraan } \\
\text { konservasi. }\end{array}$ \\
\hline $\begin{array}{l}\text { Bab VII Ketentuan Pera- } \\
\text { lihan }\end{array}$ & $\begin{array}{l}\text { Bab ini mengatur mengenai kegiatan pemungutan } \\
\text { HHBK dan izin atau perjanjian kerja sama pemanfaatan } \\
\text { HHBK yang sudah berjalan, tetap dapat dijalankan. }\end{array}$ \\
\hline Bab VIII Penutup & Mengatur mengenai mulai berlakunya Perdirjen ini. \\
\hline
\end{tabular}

\section{Tabel 4. Pembagian Bab dan Substansi \\ Pengaturan Perdirjen KSDAE No. 6/2018}

Selain itu, Tulisan ini menganggap bahwa penyelenggaraan kemitraan konservasi sebagaimana diatur dalam Perdirjen KSDAE No. 6/2018 ini terdapat 10 cara baru pengelolaan kawasan konservasi. ${ }^{48} 10$ cara baru tersebut antara lain: (a) memosisikan masyarakat sebagai subjek atau pelaku utama dalam berba- gai model pengelolaan kawasan konservasi; ${ }^{49}$ (b) penghormatan pada hak asasi manusia dengan mengupayakan penyelesaian konflik melalui dialog dengan mendorong pengembangan ekonomi kreatif berbasis sumber daya yang ada di dalam kawasan konservasi, ${ }^{50}$ (c) kerja sama lintas Eselon I Kementerian Ling-

\footnotetext{
${ }^{48}$ Wiratno, Op.Cit., hlm. 10.

${ }^{49}$ Ibid., Hlm. 10.

${ }^{50}$ Ibid., Hlm. 11.
} 
Kemitraan Konservasi Sebagai Upaya Penyelesaian Konflik Tenurial dalam Pengelolaan Kawasan

kungan Hidup dan Kehutanan dalam rangka optimalisasi pengelolaan kawasan konservasi; ${ }^{51}$ (d) kerja sama lintas kementerian, untuk mencapai sinergi dan keterpaduan program sejak dalam tahap perencanaan, pelaksanaan, dan monitoring dan evaluasi; ${ }^{52}$ (e) penghormatan nilai budaya dan adat untuk menemukan model pengelolaan kawasan konservasi yang sesuai dengan nilai-nilai budaya setempat dan dinamika geopolitik, sosial ekonomi yang terjadi di sekitar kawasan konservasi; ${ }^{53}(\mathrm{f})$ kepemimpinan multilevel untuk dapat merangkul dan mendapatkan dukungan manajemen di semua level kepemimpinan (pemerintah pusat, pemerintah daerah, pemerintah desa, dan tetua adat) $;^{54}(\mathrm{~g})$ pengambilan keputusan berbasis ilmu pengetahuan dan data yang akurat, up-to-date, dan valid dari lapangan, serta berbasis analisis yang benar sesuai dengan kaidah-kaidah ilmu pengetahuan; ${ }^{55}$ (h) pengelolaan berbasis resort di kawasan konservasi; ${ }^{56}$ (i) penghargaan dan pendampingan bagi staf yang memiliki kinerja baik dan inovatif ${ }^{57}$ (j) membangun organisasi pembelajar yang senantiasa men- dokumentasikan praktik-praktik baik pengelolaan kawasan konservasi, kemudian mencoba untuk mereplikasinya di kawasan konservasi lainnya. ${ }^{58}$

\section{Catatan Kritis Terhadap Perdirjen KSDAE No. 6/2018}

Perdirjen KSDAE No. 6/2018 dapat dikatakan sebagai terobosan yang dapat menjadi solusi terhadap konflik tenurial yang terjadi di dalam pengelolaan kawasan konservasi. Hal ini karena Perdirjen KSDAE No. 6/2018 berupaya menyeimbangkan kepentingan konservasi sekaligus menjamin kehidupan dan kesejahteraan masyarakat di dalam dan di sekitar kawasan konservasi. Namun demikian, terdapat beberapa catatan kritis terhadap Perdirjen tersebut, antara lain:

1. Terdapat perbedaan yang cukup signifikan terkait partisipasi masyarakat dalam kemitraan konservasi dalam rangka pemberdayaan masyarakat dengan kemitraan konservasi dalam rangka pemulihan ekosistem. Dalam pemberdayaan masyarakat, partisipasi masyarakat diatur mulai dari tahap persiapan, usulan rencana kegiatan, penilaian

\footnotetext{
${ }^{51}$ Ibid., Hlm. 12.

52 Ibid., Hlm. 12-13.

${ }^{53}$ Ibid., Hlm. 13.

${ }^{54}$ Ibid., Hlm. 14.

${ }^{55}$ Ibid.

${ }^{56}$ Ibid., Hlm. 16.

${ }^{57}$ Ibid., Hlm. 16-17.

${ }^{58}$ Ibid., Hlm. 17.
} 
dan persetujuan, serta perumusan dan penandatanganan perjanjian kerja sama kemitraan konservasi. ${ }^{59}$ Sedangkan dalam pemulihan ekosistem, partisipasi masyarakat hanya ketika penyusunan dan penandatanganan perjanjian kerja sama kemitraan konservasi. ${ }^{60}$ Perbedaan tingkat partisipasi ini tentu saja akan berdampak pada hasil yang berbeda terhadap pencapaian masing-masing kemitraan konservasi.

2. Pasal 2 Perdirjen KSDAE No. 6/2018 menyatakan bahwa tujuan dari kemitraan konservasi adalah mewujudkan kemandirian dan kesejahteraan masyarakat dalam rangka penguatan tata kelola dan fungsi kawasan konservasi dan kelestarian keanekaragaman hayati. ${ }^{61}$ Dalam cara pandang yang berbeda, tujuan sebagaimana Pasal 2 Perdirjen ini dapat dijadikan sebagai ukuran kinerja dari keberhasilan pelaksanaan kemitraan konservasi. Namun demikian, dalam rancangan Rencana Strategis Direktorat Jenderal Konservasi Sumber Daya Alam dan Ekosistem Tahun 2020-2024 (Renstra KSDAE 2020-
2024), target kemitraan konservasi dirumuskan dalam jumlah desa yang mendapatkan akses pengelolaan kawasan konservasi sebanyak 5000 desa. ${ }^{62}$ Target jumlah desa ini tentu saja tidak serta-merta dapat mencerminkan tujuan kemitraan konservasi, yaitu mewujudkan kemandirian dan kesejahteraan masyarakat. Oleh karena itu, Direktur Jenderal Konservasi Sumber Daya Alam dan Ekosistem (Dirjen KSDAE) harus merumuskan indikator kinerja sebagaimana tercermin dalam Pasal 2 Perdirjen ini dalam Renstra KSDAE 2020-2024, sehingga tidak hanya berbicara mengenai kuantitas pemberian akses pengelolaan kawasan konservasi kepada masyarakat, tetapi juga peningkatan kualitas dari sisi kemandirian dan kesejahteraan masyarakat.

3. Lokasi kemitraan konservasi dalam rangka pemberdayaan masyarakat meliputi zona/blok tradisional dan blok pemanfaatan kawasan pelestarian alam. ${ }^{63}$ Sedangkan lokasi kemitraan konservasi untuk pemulihan ekosistem dilakukan pada zona

\footnotetext{
${ }^{59}$ Kementerian Lingkungan Hidup dan Kehutanan (1), Op.Cit. Lihat ps. 15, ps. 16, ps. 17, ps. 18, ps. 19 , ps. 20 , ps. 21 , ps. 22, ps. 23 , dan ps. 24.

${ }^{60}$ Ibid., ps. 31, ps. 32, dan ps. 33.

${ }^{61}$ Ibid., ps. 2 ayat (2).

${ }^{62}$ Paparan Sekretariat Direktorat Jenderal Konservasi Sumber Daya Alam dan Ekosistem, Draft Rencana Strategis 2020-2024 Direktorat Jenderal KSDAE, Dipaparkan pada Rapat Penyusunan Renstra Direktorat PIKA tanggal 5-6 November 2019 di Grand Savero Hotel, Bogor.

${ }^{63}$ Kementerian Lingkungan Hidup dan Kehutanan (1), Op.Cit., Pasal 10.
} 
rehabilitasi taman nasional atau blok rehabilitasi suaka margasatwa, taman hutan raya, atau taman wisata atau areal yang telah mengalami kerusakan dan bukan pada areal jelajah satwa dilindungi atau habitat satwa dilindungi. ${ }^{64}$ Lokasi kemitraan yang dibatasi tersebut, belum tentu sesuai dengan kondisi di lapangan. Hal ini karena kegiatan pemungutan HHBK, budidaya tradisional, perburuan tradisional, dan pemanfaatan tradisional sumber daya perairan, bisa terjadi di seluruh zonasi. Penyebaran tumbuhan yang menghasilkan HHBK, juga berpotensi tersebar diseluruh zonasi. Begitu juga dengan penyebaran binatang buruan, mungkin lebih banyak di zona rimba dan zona inti yang hutannya masih bagus kondisinya. Kemudian dalam konteks pemulihan ekosistem, area yang terdegradasi tidak selalu di zona rehabilitasi dan blok rehabilitasi.

4. Kemitraan konservasi dalam rangka pemulihan ekosistem seperti memberikan beban pemulihan ekosistem kepada masyarakat. Hal ini terutama dilihat dari beberapa aspek: (a) masyarakat tidak dilibatkan dalam menyusun rencana pemulihan ekosistem, tetapi akan menjadi salah satu

\footnotetext{
${ }^{64}$ Ibid., ps. 29.

${ }^{65}$ Ibid., ps. 32 ayat (1).

${ }^{66}$ Ibid., ps. 33.

${ }^{67}$ Ibid., ps. 28 ayat (3).

${ }^{68}$ Ibid., ps. 28 ayat (4).
}

subjek utama dalam pelaksanaan pemulihan ekosistem. Keterlibatan masyarakat hanya sebatas pada forum sosialisasi ${ }^{65}$ jika masyarakat setuju dengan rencana pemulihan ekosistem kemudian disusun perjanjian kerja sama yang mencakup kesepakatan mengenai jangka waktu kemitraan dan metode pelaksanaannya; ${ }^{66}$ dan (b) hak dan kewajiban mitra konservasi dalam rangka pemulihan ekosistem. Dalam konteks hak, mitra konservasi berhak untuk mendapatkan pendampingan, memanfaatkan tumbuhan invasif yang ditebang/dimusnahkan, dan mendapatkan fasilitasi untuk beralih mata pencaharian dalam rangka mengurangi ketergantungan terhadap hutan. ${ }^{67}$ Sedangkan dalam konteks kewajiban, mitra konservasi wajib: (a) menjaga kawasan dari kebakaran, perburuan, dan perambahan; (b) melakukan kegiatan pemulihan ekosistem; (c) menjaga dan melaporkan adanya gangguan terhadap kawasan konservasi; dan (d) menanam tanaman asli atau endemik kawasan konservasi tersebut. ${ }^{68}$

5. Terdapat beberapa kegiatan dalam kemitraan konservasi yang belum secara jelas diatur dalam Perdirjen KSDAE No. 6/2018, sehingga berpotensi menimbulkan kebingungan dan 
multi interpretasi dalam implementasinya di lapangan. Pertama, kegiatan pemungutan HHBK. Sebagaimana diketahui, kegiatan terkait dengan pengambilan HHBK telah diatur dalam Peraturan Menteri Kehutanan No. P.91/Menhut-II/2014 tentang Penatausahaan Hasil Hutan Bukan Kayu Yang Berasal Dari Hutan Negara (Permenhut No. 91/2014). Dengan demikian, pelaksanaan kemitraan konservasi yang dilakukan melalui pemberian akses pemungutan HHBK harus dilakukan sesuai dengan Permenhut No. 91/2014, terutama untuk kegiatan pengambilan HHBK untuk tujuan komersial. ${ }^{69}$ Sehingga dalam pelaksanaan kemitraan konservasi melalui kegiatan pemungutan HHBK perlu mempersiapkan mitra konservasi untuk dapat melaksanakan ketentuan Permenhut No. 91/2014 tersebut. Kedua, kegiatan budidaya tradisional untuk kebutuhan sehari-hari, terutama kelompok tanaman biji-bijian. Perdirjen KSDAE No. 6/2018 belum mengatur secara jelas tanaman biji-bijian yang boleh ditanam di kawasan konservasi. Di lapangan banyak ditemukan berbagai macam budidaya tradisional untuk tanaman biji- -bijian seperti padi, cokelat, dan kopi. Apakah ketiga jenis tanaman biji-bijian tersebut boleh ditanam di kawasan konservasi, padahal ketiganya bukan termasuk tanaman hutan.

6. Perdirjen KSDAE No. 6/2018 mengatur mengenai Mitra Konservasi yang mencakup: (a) orang perseorangan; (b) kelompok orang; (c) masyarakat hukum adat; dan (d) masyarakat setempat. ${ }^{70}$ Kemudian ada penekanan bahwa kelompok sasaran tersebut: (a) tinggal di sekitar dan/atau di dalam kawasan konservasi; (b) kehidupannya memiliki keterkaitan dan ketergantungan pada potensi dan sumber daya alam di kawasan konservasi, dan/atau (c) turun-temurun mempunyai ketergantungan terhadap sumber daya alam di zona tradisional untuk memenuhi kebutuhan kehidupan sehari-hari.

Di satu sisi, keberagaman mitra konservasi ini menunjukkan bahwa kemitraan konservasi mencakup masyarakat dalam spektrum yang luas, namun demikian, secara bersamaan, keberagaman mitra konservasi tersebut menjadi tantangan tersendiri bagi Direktorat Jenderal Konservasi Sumber Daya Alam dan Ekosistem (Ditjen KSDAE) dan kepala unit pe-

\footnotetext{
${ }^{69}$ Ibid., ps. 5 ayat (4).

${ }^{70}$ Ibid., ps. 1 angka 11, angka 12, angka 13, angka 14, dan angka 18.
} 
Kemitraan Konservasi Sebagai Upaya Penyelesaian Konflik Tenurial dalam Pengelolaan Kawasan

ngelola kawasan konservasi. Hal ini karena masing-masing individu dan kelompok masyarakat memiliki motivasi dan kegiatan yang berbeda-beda, terlebih lagi ketika mitra konservasi tersebut kemudian ditumpangi oleh pemilik modal yang ingin memanfaatkan lahan di kawasan konservasi melalui mitra konservasi (free rider).

\section{Optimalisasi Implementasi Ke- mitraan Konservasi Sesuai De- ngan Perdirjen KSDAE No. 6/2018 dalam Rangka Menyele- saikan Konflik Tenurial di Ka- wasan Konservasi}

Sebagaimana telah diuraikan sebelumnya, bahwa kebijakan kemitraan konservasi sebenarnya sudah mendapatkan jaminan hukumnya sejak lahirnya UU No. 5/1990 hingga saat ini dengan lahirnya Perdirjen KSDAE No. 6/2018, meskipun dengan tingkat gradasi im- plementasi yang berbeda-beda. Namun demikian, dalam konteks implementasi kemitraan konservasi berdasarkan Perdirjen KSDAE No. 6/2018 ini, Dirjen KSDAE tengah mengupayakan kombinasi kebijakan untuk mengoptimalkan implementasi Perdirjen KSDAE No. 6/2018 ini, antara lain:

1. Memasukkan secara spesifik capaian kemitraan konservasi dalam rancangan Renstra KSDAE Tahun 20202024, yaitu dengan mencantumkan target jumlah desa yang mendapatkan akses pengelolaan kawasan konservasi sebanyak 5000 desa; ${ }^{71}$

2. Menjadikan kemitraan konservasi sebagai salah satu rekomendasi pilihan penyelesaian konflik tenurial dalam panduan dan rumusan tipologi konflik tenurial di kawasan konservasi yang akan menjadi kebijakan terbaru Ditjen KSDAE.72

71 Paparan Sekretariat Direktorat Jenderal Konservasi Sumber Daya Alam dan Ekosistem, Draft Rencana Strategis 2020-2024 Direktorat Jenderal KSDAE, Dipaparkan pada Rapat Penyusunan Renstra Direktorat PIKA tanggal 5-6 November 2019 di Grand Savero Hotel, Bogor.

${ }^{72}$ Draft Rumusan Tipologi Konflik Tenurial di Kawasan Konservasi yang disusun oleh Direktorat Kawasan Konservasi, Direktorat Jenderal Konservasi Sumber Daya Alam dan Ekosistem, Kementerian Lingkungan Hidup dan Kehutanan, disebutkan beberapa strategi penyelesaian konflik tenurial, yaitu: (a) mediasi dengan mengacu pada Peraturan Direktur Jenderal Perhutanan Sosial dan Kemitraan Lingkungan No. P.4/PSKL/SET/PSL.1/4/2016; (b) penegakan hukum dengan mengacu pada UU No. 5/1990; (c) kemitraan dalam rangka pemberdayaan masyarakat dan dalam rangka pemulihan ekosistem yang mengacu pada Perdirjen No. 6/2018; (d) resettlement yang mengacu pada Peraturan Presiden No. 88 Tahun 2017; (e) Tanah Objek Reforma Agraria (TORA)/pelepasan kawasan yang mengacu pada Peraturan Presiden No. 88 Tahun 2017; (f) review zona/blok yang mengacu pada Peraturan Menteri Lingkungan Hidup dan Kehutanan No. P.76/Menlhk-Setjen/2015; (g) koordinasi antara Direktorat Jenderal KSDAE dengan Direktorat Jenderal PKTL yang mengacu pada regulasi terkait dengan pengukuhan kawasan; (h) koordinasi antara Direktorat Jenderal KSDAE dengan Direktorat Jenderal PSKL yang mengacu pada Peraturan Menteri Lingkungan Hidup dan Kehutanan No. P.32/Menlhk-Setjen/2015 dan Peraturan Direktur Jenderal Perhutanan Sosial dan Kemitraan Lingkungan No. P.1/PSKL/SET/ KUM.1/2/2016. 
3. Menyusun data dan peta opened rrea $^{73}$ sebagai baseline dalam menyelesaikan konflik tenurial di kawasan konservasi. Peta opened area ini kemudian akan dilakukan updating dan pendetailan oleh unit pengelola kawasan konservasi, sehingga akan dapat dirumuskan tipologi konflik tenurialnya, sekaligus rekomendasi penyelesaiannya. ${ }^{74}$ Dalam dokumen RPJMN 2020-2024, luas opened area mencapai 1,8 juta hektare. ${ }^{75}$

4. Menyusun peta indikatif kemitraan konservasi untuk 554 kawasan konservasi. Peta indikatif ini menjadi $b a-$ seline dan rujukan resmi bagi direktorat teknis dan unit pengelola kawasan konservasi dalam mendorong kemitraan konservasi di masing-masing unit pengelolaan. Hingga Maret 2019, area indikatif kemitraan konservasi seluas 3.452.172 hektare, dengan rincian 747.840,33 untuk skema pemulihan ekosistem, 1.329.269,82 untuk skema pemberdayaan masyarakat dalam bentuk pemberian akses, dan $1.375 .062,82$ untuk skema pem- berdayaan masyarakat dalam bentuk kerja sama antara pemegang izin dengan masyarakat. ${ }^{76}$

\section{Penutup}

Disahkan dan diundangkannya Perdirjen KSDAE No. 6/2018 yang mengatur mengenai kemitraan konservasi merupakan win-win solution dalam rangka menyeimbangkan kepentingan konservasi dan menjamin kehidupan dan kesejahteraan masyarakat di dalam dan di sekitar kawasan konservasi. Terlebih lagi, dalam mengoptimalkan implementasi Perdirjen KSDAE No. 6/2018, Dirjen KSDAE juga mengombinasikan dengan beberapa kebijakan lain, seperti memasukkan dalam Renstra KSDAE 20202024, memasukkan sebagai salah satu rekomendasi pilihan penyelesaian konflik tenurial di kawasan konservasi, penyusunan data dan peta opened area dan peta indikatif kemitraan konservasi. Tulisan ini mengakui dan mengapresiasi kombinasi kebijakan ini sebagai comprehensive approach dalam menyelesaikan konflik tenurial di kawasan konservasi.

${ }^{73}$ Opened area merupakan area di kawasan konservasi yang dirambah atau digunakan untuk kepentingan diluar kegiatan pembangunan kehutanan maupun konservasi. Misalnya, areal tambang, pemukiman, ladang, sawah, tanaman selain tanaman asli kawasan konservasi, dll.

${ }^{74}$ Direktorat Pemolaan dan Informasi Konservasi Alam, Direktorat Jenderal Konservasi Sumber Daya Alam dan Ekosistem, Kementerian Lingkungan Hidup dan Kehutanan, Nota Dinas No. ND.166/ PIKA/IIKA/KSA.0/3/2019.

${ }^{75}$ Indonesia (3), Peraturan Presiden Republik Indonesia No. 18 Tahun 2020 tentang Rencana Pembangunan Jangka Menengah Nasional 2020-2024. Lampiran Matriks Pembangunan dan Matriks Pembangunan Jangka Menengah Kementerian/Lembaga, hlm. A.1.4.

${ }^{76}$ Direktorat Pemolaan dan Informasi Konservasi Alam, Op.Cit. 
Namun demikian, untuk memperkuat implementasi kemitraan konservasi dalam rangka menyelesaikan konflik tenurial di kawasan konservasi, sekaligus menyeimbangkan antara kepentingan konservasi dan menjamin kehidupan dan kesejahteraan masyarakat di dalam dan di sekitar kawasan konservasi, Tulisan ini merekomendasikan beberapa hal: (a) Revisi terbatas Perdirjen KSDAE No. 6/2018, khususnya untuk memperkuat partisipasi masyarakat dalam kemitraan konservasi dalam rangka pemulihan ekosistem; memperjelas ukuran kinerja dan keberhasilan pelaksanaan kemitraan konservasi; mengatur ulang lokasi kemitraan konservasi yang sesuai dengan kondisi di lapangan; memberikan jaminan manfaat, serta hak dan ke- wajiban yang seimbang bagi masyarakat yang terlibat dalam kemitraan konservasi dalam rangka pemulihan ekosistem; memperjelas kegiatan dalam kemitraan konservasi, khususnya terkait dengan kegiatan pemungutan HHBK dan jenis-jenis tanaman budidaya tradisional yang diperbolehkan ditanam di kawasan konservasi; dan mekanisme untuk mendeteksi dan meminimalisasi adanya free rider dalam pelaksanaan kemitraan konservasi; (b) menyosialisasikan Perdirjen KSDAE No. 6/2018 kepada masyarakat di dalam dan di sekitar kawasan konservasi; dan (c) meningkatkan kapasitas staf unit pengelola kawasan konservasi untuk dapat menerapkan Perdirjen KSDAE No. 6/2018 sebagai bagian dari pilihan penyelesaian konflik tenurial. 


\section{DAFTAR PUSTAKA}

\section{Peraturan Perundang-Undangan}

Indonesia, Undang-Undang No. 5 Tahun 1990 tentang Konservasi Sumber Daya Alam Hayati dan Ekosistemnya. Undang-Undang No. 41 Tahun

1999 tentang Kehutanan. Peraturan Presiden Republik Indonesia No. 18 Tahun 2020 tentang Rencana Pembangunan Jangka Menengah Nasional 2020-2024

Kementerian Lingkungan Hidup dan Kehutanan, Peraturan Direktur Jenderal Konservasi Sumber Daya Alam dan Ekosistem No. P.6/ KSDAE / SET / Kum.1/6/2018 tentang Petunjuk Teknis Kemitraan Konservasi Pada Kawasan Suaka Alam dan Kawasan Pelestarian Alam.

, Peraturan Menteri Lingkungan

Hidup dan Kehutanan No..44/ MENLHK/SETJEN/KUM.1/6/2017 tentang Perubahan Atas Peraturan Menteri Kehutanan No. P.85/ Menhut-II/2014 tentang Tata Cara Kerjasama Penyelenggaraan Kawasan Suaka Alam dan Kawasan Pelestarian Alam.

Peraturan Menteri Lingkungan Hidup dan Kehutanan No. P.43/ MENLHK/SETJEN/KUM.1/6/2017 tentang Pemberdayaan Masyarakat di Sekitar Kawasan Suaka Alam dan Kawasan Pelestarian Alam.

Peraturan Menteri Lingkungan

Hidup dan Kehutanan No. P.83/ M E N L H K / S E T J E N /
KUM.1/10/2016 tentang Perhutanan Sosial.

Kementerian Kehutanan, Peraturan Menteri Kehutanan No. P.85/ Menhut-II/2014 tentang Tata Cara Kerjasama Penyelenggaraan Kawasan Suaka Alam dan Kawasan Pelestarian Alam. Peraturan Menteri Kehutanan No. P.39/Menhut-II/2013 tentang Pemberdayaan Masyarakat Setempat Melalui Kemitraan Kehutanan. Peraturan Menteri Kehutanan No. P.56/Menhut-II/2006 tentang Pedoman Zonasi Taman Nasional. Peraturan Menteri Kehutanan No. P.19/Menhut-II/2004 tentang Kolaborasi Pengelolaan Kawasan Suaka Alam dan Kawasan Pelestarian Alam.

\section{Buku}

Kepala Sub Bagian Data dan Informasi Sekretariat Direktorat Jenderal KSDAE. Statistik Direktorat Jenderal Konservasi Sumber Daya Alam dan Ekosistem 2017, Jakarta: Kementerian Lingkungan Hidup dan Kehutanan, Direktorat Jenderal Konservasi Sumber Daya Alam dan Ekosistem, 2018.

Kusumasumantri, Pandji Yudistira. Sejarah 5 Taman Nasional Pertama. Jakarta: Kementerian Lingkungan Hidup dan Kehutanan, Direktorat Jenderal Konservasi Sumber Daya Alam dan Ekosistem, [s.a.]. 
Kemitraan Konservasi Sebagai Upaya Penyelesaian Konflik Tenurial dalam Pengelolaan Kawasan

Mulyana, Agus, dkk. Ruang Adaptif: Refleksi Penataan Zona/BlokDi Kawasan Konservasi. Jakarta: Kementerian Lingkungan Hidup dan Kehutanan, Direktorat Jenderal Konservasi Sumber Daya Alam dan Ekosistem, 2019.

Wiratno, 10 Cara Baru Kelola Kawasan KonservasidiIndonesia:Membangun "Organisasi Pembelajar," Jakarta: Direktorat Jenderal Konservasi Sumber Daya Alam dan Ekosistem, Kementerian Lingkungan Hidup dan Kehutanan, 2018.

Yudistira, Pandji. Sang Pelopor: Peranan Dr. S.H. Koorders dalam Sejarah Perlindungan Alam di Indonesia. Jakarta: Kementerian Kehutanan, Direktorat Kawasan Konservasi dan Bina Hutan Lindung, Direktorat Jenderal Perlindungan Hutan dan Konservasi Alam, 2014.

\section{Jurnal}

Mahmud, Amir, Arif Satria, dan Rilus A Kinseng. "Analisis Sejarah dan Pendekatan Sentralisasi dalam Pengelolaan Taman Nasional Bali Barat," Jurnal Analisis Kebijakan Kehutanan Vol. 12 No. 2, Agustus 2015.

Purwawangsa, Handian. "Instrumen Kebijakan Untuk Mengatasi Konflik di Kawasan Hutan Konservasi," Jurnal Risalah Kebijakan Pertanian dan Lingkungan Vol. 4 No.1, April 2017.

\section{Lain-Lain}

Badan Pusat Statistik, Berita Resmi Statistik: Hasil Pendataan Potensi Desa (Podes) 2018 No. 99/12/Th. XXI, 10 Desember 2018.

Direktorat Pemolaan dan Informasi Konservasi Alam, Direktorat Jenderal Konservasi Sumber Daya Alam dan Ekosistem, Kementerian Lingkungan Hidup dan Kehutanan, Nota Dinas No. ND.166/PIKA/IIKA/ KSA.0/3/2019.

Draft Rumusan Tipologi Konflik Tenurial di Kawasan Konservasi yang disusun oleh Direktorat Kawasan Konservasi, Direktorat Jenderal Konservasi Sumber Daya Alam dan Ekosistem, Kementerian Lingkungan Hidup dan Kehutanan.

Kementerian Lingkungan Hidup dan Kehutanan, "Refleksi Hutan Sosial KLHK 2018: Hutan Untuk Rakyat," Siaran Pers No. SP.723/HUMAS/ PP/HMS.3/12/2018, (http://ppid. menlhk.go.id/siaran_pers / browse/1718).

Paparan Sekretariat Direktorat Jenderal Konservasi Sumber Daya Alam dan Ekosistem, Draft Rencana Strategis 2020-2024 Direktorat Jenderal KSDAE. 